classified according to their provenance, and full descriptions and illustrations are given of a large number of typical examples.

Two other papers in the volume deserve special mention, as they illustrate another side of the Museum's activities. In addition to their purely scientific work,

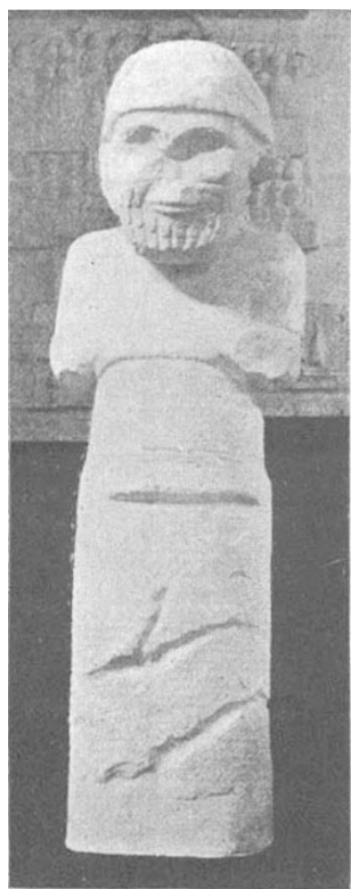

EIG. 2.-Colossal Statue of the God Hadad, Gertch in, Northern Syria,

special attention is now being given by its officers to the function of the Museum as an educational institution, and to the popularisation of the collections. At the International Exposition held at Atalanta in 1895. special collections were organised and arranged for the illustration of distinct subjects of study, and the de- from ancient as well as modern times throw valuable light on the text of the Old Testament narratives; one of the plates, for instance, which is here reproduced, is intended to illustrate some of the wind instruments mentioned in the Bible (Fig. I). Moreover, by means of a fine series of casts, reproduced by photography, the antiquities of Western Asia during the principal periods of Old Testament history are fully represented. Two good specimens of these are here given-a colossal statue of the god Hadad from Northern Syria (Fig. 2), and a bas-relief of a lion chase in the so-called "Hittite" style (Fig. 3), which exhibits many interesting points of resemblance to its Assyrian prototypes. The other paper deals with "Chess and Playing Cards," and consists of a catalogue of games and implements of divination, which were also exhibited at Atalanta. This collection was formed by the Museum in collaboration with the University of Pennsylvania, and it is here described by Mr. Stewart Culin, the director of the Museum of Archæology and Palæontology in that University. We have not done more than indicate the varied nature of the contents of this report, but sufficient has been said to show that the study of science and archæology in the United States is receiving valuable encouragement from the Government, and that the system and methods there adopted compare very favourably with those in many European museums.

AN IMPROVED LIQUID INTERRUPTER FOR INDUCTION COILS.

THE following is a description of an improved form of Wehnelt-Caldwell interrupter for induction coils, devised by the writer in conjunction with Mr. J. C. M. Stanton and Mr. H. Tyson Wolff.

The two electrodes of sheet lead $\mathrm{C}$ and $\mathrm{D}$ dip into dilute sulphuric acid, contained in the glass vessel A. The electrodes are separated by a hollow glass or porcelain cylinder $\mathrm{B}$, which surrounds the electrode $\mathrm{C}$. This cylinder is closed at the bottom with the exception of a circular aperture $\mathrm{E}$, about three or four millimetres in diameter. Through this aperture projects the small end of the conical glass or porcelain valve $F$, which by means of the screwed carrier tube $\mathrm{H}$ and the milled nut $\mathrm{G}$, can be raised or lowered so as to open or close the aperture to any desired extent. As when the apparatus is at work

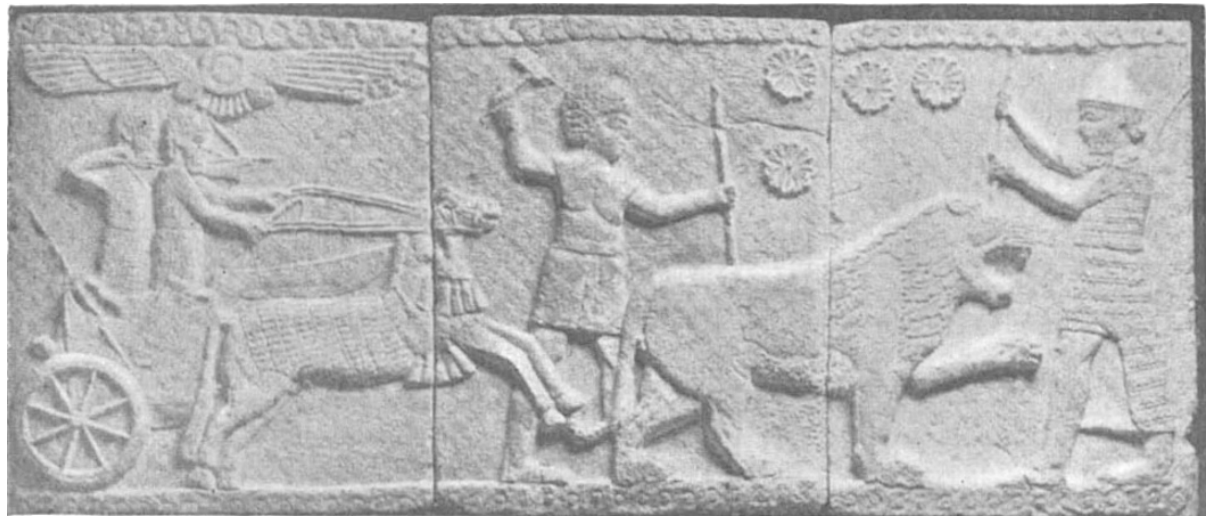

FrG. 3.-Hittite Lion Chase.

scriptions that were published at the time are here reprinted as a record of the collections that were shown. Of these papers, that on "Biblical Antiquities" is written by Dr. Cyrus Adler and Dr. Cassanowitz, who describe a number of exhibits illustrating the geology, flora and fauna of Palestine, while other exhibits dating the liquid is found to rise in the cylinder $B$, the latter is provided with an overflow at $\mathrm{J}$.

The interruptions take place in the valve aperture, and appear to be due to the formation of gas or steam therein. The extent to which the valve is open or shut determines the amount of current passed, and the NO. I 549 , VOL. 60 ] 
frequency within wide limits. The wider the valve is open the larger is the current, and the lower is the frequency, and vice versâ. With this apparatus in circuit with a Io-inch coil connected direct on to the roo-volt supply mains, it was found that by adjusting the valve the primary current could be altered from o to 25 amperes, while the pitch of the sound of the discharge could be changed from a very shrill whistle down to a rattling roar. By introducing additional self-induction into the circuit the frequency can be lowered still further.

The direction of the current through the apparatus does not affect the results, and the arrangement, when suitably adjusted, works well with alternating current, the sparks in each direction being of equal power. The troublesome fatigue phenomena to which the Wehnelt

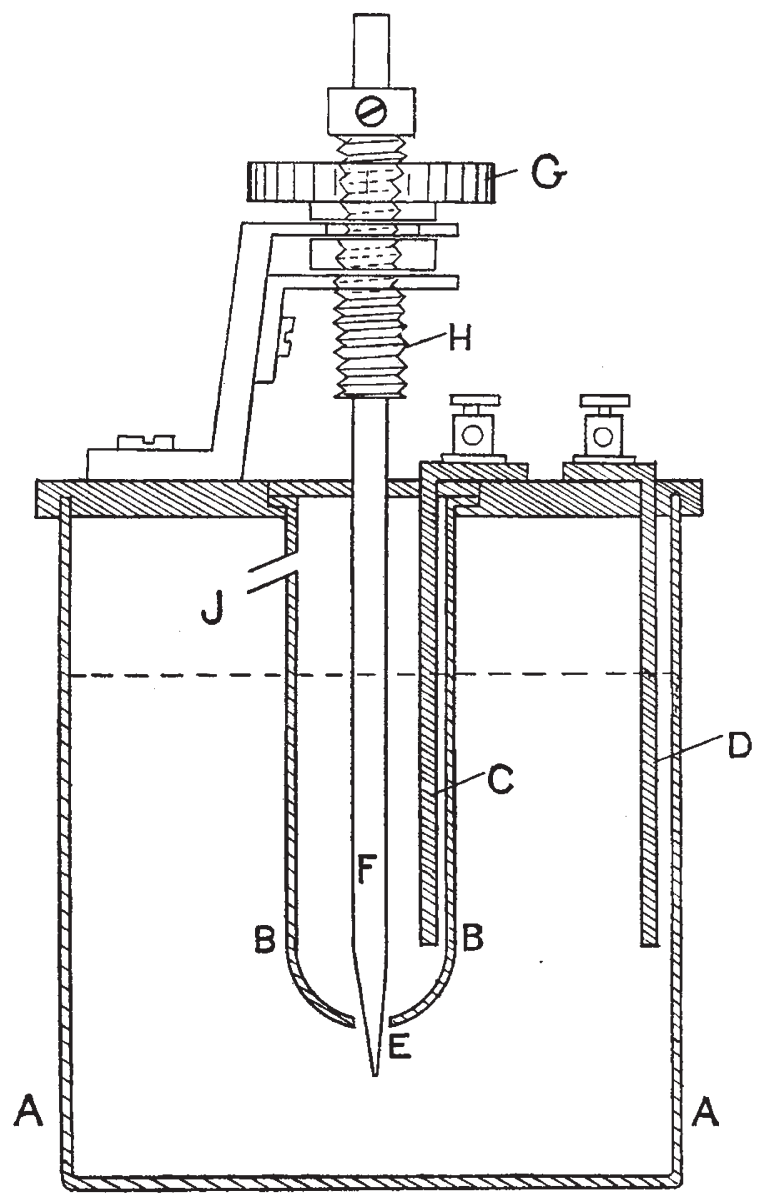

instrument is liable appear to be absent, while the difficulties as to the fusing of the platinum wire and the cracking of its insulating sheath are also avoided. This improved instrument has in fact all the advantages of that of Caldwell, of which it is a modification, with the further advantage of easy adjustment to suit different voltages, and to give different amounts of power and different frequencies.

A. A. Campbell Swinton.

\section{THE SEVENTH INTERNATIONAL}

\section{GEOGRAPHICAL CONGRES.S.}

$A \mathrm{~T}$ the meeting of the sixth International Geographical Congress in London in 1895 , it was decided that the seventh should take place in Berlin in 1899 . The Berlin Geographical Society, according to the precedent of previous Congresses, undertook the necessary arrange- ments, and these have now been perfected. The Congress will differ from that of London by the absence of a geographical exhibition, and by the more thorough organisation of scientific excursions under specialist leaders before and after the meeting.

The proceedings will commence informally by an evening gathering on Wednesday, September 27, when an opportunity will be afforded for conversation amongst the members. Next day the formal opening of the Congress will take place in the splendid new buildings of the Prussian House of Representatives, which has been. generously placed at the disposal of the Congress for the whole meeting. As in London, the proceedings of each day will include a forenoon sitting for the discussion of papers of general interest, and several sectional meetings in the afternoon for subjects which appeal to a limited number of specialists.

The Bureau of the 'Sixth Congress (of which Sir Clements Markham is President and Dr. Scott Keltie and Dr. H. R. Mill Honorary Secretaries) will present a report and resign its functions to that of the new Congress, the President of which is Baron von Richthofen and the Secretary Hauptmann Kollm. The various. committees of the seventh Congress, honorary and executive, bear the names of the most distinguished geographers of all countries, and the gathering promises. to be a really representative one.

The papers which have been promised are grouped into seven main divisions, viz. mathematical geography, physical geography, biogeography, anthropogeography, exploration, historical geography, and geographical education. The papers will be very numerous, but as a strict time limit of twenty minutes is to be enforced, there will be an opportunity for effective discussion.

Some of the most interesting subjects to be dealt with in the first group are the position of mean sea-level, the present state of research on the tides, and seismology, while in physical geography Prof. W. M. Davis and Prof. de Lapparent will deal with questions of geomorphology, and oceanography will be treated in great detail in conjunction with polar research.

Dr. Nansen, Sir John Murray, the Prince of Monaco, Prof. Chun (of the Valdivia expedition), Profs. Pettersson, Thoulet, \&c., have all promised to take part. The plans of the German Antarctic expedition will be explained by Dr. von Drygalski, the chosen leader; while Sir Clements Markham and Sir John Murray will give an account of the progress of the arrangements of the British Antarctic expedition. It is hoped that a general scheme may be agreed upon for simultaneous and strictly comparable observations, so that by combined action the two expeditions will secure the maximum result for their labours.

The distribution of plants will be dealt with by Profs. Engler, Drude and others, while numerous papers on other branches of physical geography are promised.

Under the head of "Exploration," the names of several Germans are announced, but no British subjects have come forward to claim international importance for their journeys.

One feature of the Congress which promises a practical outcome is the prominence which is given to questions of nomenclature. Prof. Richter (of Graz) will propose a systematic terminology for use in research on glaciers ; and the terminology and nomenclature of the forms of the ocean floor will be discussed by Profs. Wagner, Krümmel, Voiekoff, and Dr. H. R. Mill. Proposals for the uniform use of the metric system and the centigrade temperature scale in all geographical work will also be put forward.

The scientific excursions, which for the most part precede the meeting of the Congress, have been well organised. The programme has just been issued, giving particulars as to route, leaders, terms, \&c., and also containing a list of the best maps and guide-books, and a

NO. I 549, VOL. 6o] 